\title{
Antibiotic resistance in the pathogenic foodborne bacteria isolated from raw kebab and hamburger: phenotypic and genotypic study
}

\author{
Maryam Rajaei ${ }^{1}$, Mir-Hassan Moosavy ${ }^{1 *}$, Sahar Nouri Gharajalar ${ }^{2}$ and Seyed Amin Khatibi ${ }^{1}$
}

\begin{abstract}
Background: In recent years, interest in the consumption of ready-to-eat (RTE) food products has been increased in many countries. However, RTE products particularly those prepared by meat may be potential vehicles of antibioticresistance foodborne pathogens. Considering kebab and hamburger are the most popular RTE meat products in Iran, this study aimed to investigate the prevalence and antimicrobial resistance of common foodborne pathogens (Escherichia coli, Salmonella spp., Staphylococcus aureus, and Listeria monocytogenes) in raw kebab and hamburger samples collected from fast-food centers and restaurants. Therefore, total bacterial count (TBC), as well as the prevalence rates and antibiogram patterns of foodborne pathogens in the samples were investigated. Also, the presence of antibiotic-resistance genes ( $b / a_{\mathrm{SHV}}, b / a_{\mathrm{TEM}}, b / a_{\mathrm{Z}}$ and mecA) was studied in the isolates by PCR.

Results: The mean value of TBC in raw kebab and hamburger samples was $6.72 \pm 0.68 \mathrm{log}$ CFU/g and $6.64 \pm 0.66$ $\log \mathrm{CFU} / \mathrm{g}$, respectively. E. coli had the highest prevalence rate among the investigated pathogenic bacteria in kebab (70\%) and hamburger samples (48\%). Salmonella spp., L. monocytogenes, and S. aureus were also recovered from 58, 50 , and $36 \%$ of kebab samples, respectively. The contamination of hamburger samples was detected to $S$. aureus (22\%), L. monocytogenes (22\%), and Salmonella spp. (10\%). In the antimicrobial susceptibility tests, all isolates exhibited high rates of antibiotic resistance, particularly against amoxicillin, penicillin, and cefalexin (79.66-100\%). The bla $a_{\text {TEM }}$ was the most common resistant gene in the isolates of E. coli (52.54\%) and Salmonella spp. (44.11\%). Fourteen isolates (23.72\%) of E. coli and 10 isolates (29.41\%) of Salmonella spp. were positive for bla $a_{\mathrm{SHV}}$. Also, 16 isolates (55.17\%) of S. aureus and 10 isolates (27.27\%) of L. monocytogenes were positive for mecA gene.
\end{abstract}

Conclusions: The findings of this study showed that raw kebab and hamburger are potential carriers of antibioticresistance pathogenic bacteria, which can be a serious threat to public health.

Keywords: Foodborne pathogens, Kebab, Hamburger, Antibiogram, Antibiotic-resistance genes

*Correspondence: mhmoosavy@gmail.com; moosavy@tabrizu.ac.ir ${ }^{1}$ Department of Food Hygiene and Aquatic, Faculty of Veterinary Medicine, University of Tabriz, Tabriz, Iran

Full list of author information is available at the end of the article

\section{Background}

Antibiotics are commonly used for the treatment of infectious diseases in humans and animals [1-3]. In recent years, the excessive and uncontrolled use of antibiotics in veterinary medicine has become a major area of concern for human health. One of the main consequences of antibiotic residues in foods of animal origin is the proliferation of antibiotic-resistant bacteria. The 
presence of antibiotic-resistant pathogenic bacteria in foods may lead to hard-to-treat foodborne infections in humans. They can also transfer the resistance genes to other microorganisms through the food chain [2-5].

Multidrug resistance has increased globally that is considered a public health threat. Several previous investigations revealed the emergence of multidrug-resistant bacterial pathogens from different origins especially, in the food chain that increases the need for proper application of the antimicrobial agents in both veterinary and health sectors [6-13].

Antibiotic resistance limits the selection of therapeutic agents and increases the potential for treatment failures and adverse clinical complications. The presence of extended-spectrum antibiotic resistance genes (such as extended-spectrum beta-lactamases) in bacteria has been a major concern for public health [14].

Nowadays, due to the problems caused by industrialization, the interest of people toward the use of ready-toeat (RTE) products has been increased [15]. However, these products may be prepared at low hygienic conditions by food handlers [16-18]. Therefore, RTE foods, particularly those prepared by meat, have been considered as potential vehicles of bacterial foodborne pathogens [17]. Meat is known as a rich source of high-quality animal proteins, vitamins $B$, and most of the trace minerals which are essential in human nutrition [19]. Due to the nutrient contents of meat, it provides an ideal medium for the growth of microorganisms [20].

Food products of animal origin such as meat and meat products are the main vehicles for the transmission of food-borne zoonotic bacterial pathogens. Escherichia coli (E. coli), Staphylococcus aureus (S. aureus), Salmonella spp. and Listeria monocytogenes (L. monocytogenes) have been known as the major zoonotic bacterial pathogens which are associated with many cases of foodborne illness and death in humans following the consumption of contaminated food in the world [21-26].

Meat and meat products may be an important vehicle for the dissemination of antibiotic-resistant pathogenic bacteria [1-3, 27]. Several studies in recent years have been reported the presence of antibiotic-resistance bacteria in meat and meat products [27-31]. Therefore, monitoring the prevalence of antibiotic-resistance microorganisms not only is necessary to provide enough knowledge about the magnitude of this problem but also help governmental authorities to evaluate the effectiveness of control measures [2-4].

Due to the lack of proper surveillance systems in developing countries such as Iran, there are little scientific data available regarding the prevalence of foodborne pathogens in RTE meat products in these countries. Moreover, the antimicrobial resistance of foodborne pathogens in kebab and hamburgers were rarely investigated. To date, there is little knowledge about the relationship that may exist between antibiotic resistance phenotypes and resistance genes in pathogenic organisms isolated from RTE meat products.

Kebab and hamburger are the most commonly used RTE meat products in Iran. Therefore, the current study was aimed to evaluate the prevalence, and the phenotypic and genotypic profile of antibiotic-resistance E. coli, Salmonella spp., S. aureus, and L. monocytogenes isolated from raw kebab and hamburger samples which was collected from fast-food centers and restaurants in the northwest of Iran. Also, the presence of antibiotic resistance genes of $b l a_{\mathrm{TEM}}, b l a_{\mathrm{SHV}}, b l a_{\mathrm{Z}}$, and mecA were investigated in the isolates.

\section{Results}

Total bacterial count (TBC)

The mean total colony forming unit per gram $(\mathrm{CFU} / \mathrm{g})$ of raw kebab $(n=50)$ and hamburger samples $(n=50)$ was $6.72 \pm 0.68 \log$ CFU/g and $6.64 \pm 0.66 \log$ CFU/g, respectively. However, the difference between the mean values of TBC in kebab and hamburger samples was not statistically significant $(p>0.05)$.

\section{Prevalence of different foodborne pathogens}

E. coli had the highest prevalence rate $(70 \%)$ in kebab samples between the investigated pathogenic bacteria. Salmonella spp., L. monocytogenes, and S. aureus were found in 58, 50, and $36 \%$ of kebab samples, respectively. Also, high rates of contamination to E. coli (48\%), $S$. aureus (22\%), L. monocytogenes (22\%), and Salmonella spp. (10\%) were detected in hamburger samples (Table 1).

\section{Antibiotic susceptibility patterns of the retrieved bacterial pathogens}

The resistance pattern of $E$. coli to the antibiotics studied is shown in Table 2 and Fig. 1A. The highest antibiotic resistance of $E$. coli isolated from kebab and hamburger samples was to penicillin (100\%) followed by cephalexin $(86.27 \%)$ and amoxicillin $(80.00 \%)$, respectively. The

Table 1 Prevalence of different foodborne pathogens in raw kebab and hamburger samples

\begin{tabular}{lll}
\hline Bacteria & $\begin{array}{l}\text { Kebab }(\boldsymbol{n}=\mathbf{5 0}) \\
\text { No. of positive samples }\end{array}$ & $\begin{array}{l}\text { Hamburger }(\boldsymbol{n}=\mathbf{5 0}) \\
\text { No. of positive samples }\end{array}$ \\
\hline S. aureus & $18(36 \%)$ & $11(22 \%)$ \\
E. coli & $35(70 \%)$ & $24(48 \%)$ \\
Salmonella spp. & $29(58 \%)$ & $5(10 \%)$ \\
L. monocytogenes & $25(50 \%)$ & $11(22 \%)$ \\
\hline
\end{tabular}


Table 2 Antibiotic resistance profile of Escherichia coli isolates from raw kebab and hamburger samples

\begin{tabular}{|c|c|c|c|c|c|c|c|c|}
\hline \multirow[t]{2}{*}{ Antibiotic class } & \multirow[t]{2}{*}{ Specific antibiotic tested } & \multirow[t]{2}{*}{ Concentration } & \multicolumn{3}{|c|}{$\begin{array}{l}\text { Interpretive categories and zone } \\
\text { diameter breakpoints (nearest } \\
\text { whole } \mathrm{mm} \text { ) }^{\mathrm{a}}\end{array}$} & \multicolumn{3}{|c|}{ No. of isolates/Total isolates } \\
\hline & & & $\mathbf{R}^{\mathbf{b}}$ & $\mathbf{I}$ & $S$ & $\mathbf{R}$ & $I$ & $\mathrm{~S}$ \\
\hline Macrolides & Azithromycin & $15 \mu g$ & $\leq 12$ & - & $\geq 13$ & $34 / 59$ & - & $25 / 59$ \\
\hline \multirow[t]{2}{*}{ Cephalosporins } & Ceftriaxone & $30 \mu \mathrm{g}$ & $\leq 19$ & $20-22$ & $\geq 23$ & $7 / 59$ & $6 / 59$ & $46 / 59$ \\
\hline & Cephalexin & $30 \mu \mathrm{g}$ & $\leq 14$ & - & $\geq 15$ & $51 / 59$ & - & $8 / 59$ \\
\hline \multirow[t]{2}{*}{ Penicillins } & Penicillin & $10 / U$ & $\leq 14$ & - & $\geq 15$ & $59 / 59$ & - & $0 / 59$ \\
\hline & Amoxicillin & $25 \mu \mathrm{g}$ & $\leq 13$ & $14-16$ & $\geq 17$ & $47 / 59$ & $5 / 59$ & $7 / 59$ \\
\hline Aminoglycosides & Gentamicin & $10 \mu \mathrm{g}$ & $\leq 12$ & $13-14$ & $\geq 15$ & $5 / 59$ & $0 / 59$ & $54 / 59$ \\
\hline Tetracyclines & Tetracycline & $30 \mu g$ & $\leq 11$ & $12-14$ & $\geq 15$ & $38 / 59$ & $3 / 59$ & $18 / 59$ \\
\hline Phenicols & Chloramphenicol & $30 \mu \mathrm{g}$ & $\leq 12$ & $13-17$ & $\geq 18$ & $8 / 59$ & $11 / 59$ & $40 / 59$ \\
\hline
\end{tabular}

a From CLSI [32]

${ }^{\mathrm{b}} \mathrm{R}$ resistant, I intermediate, $\mathrm{S}$ susceptible

highest antibiotic susceptibility of the isolates was observed to gentamicin (91.11\%), ceftriaxone (78.00\%), and chloramphenicol (67.34\%), respectively. Resistance to $\geq 2$ antimicrobials was found in all $E$. coli isolates. Three isolates of $E$. coli from hamburgers were resistant to all tested antibiotics (Table 6).

L. monocytogenes isolates had the highest resistance against penicillin (100\%), amoxicillin (100\%), and cephalexin (93.75\%) (Table 3) (Fig. 1B). Multidrug resistance to 6 antibiotics was observed in $42.66 \%$ of L. monocytogenes isolates including $48.00 \%$ of kebab isolates and $27.27 \%$ of hamburger isolates (Table 6).

The highest antibiotic resistance of Salmonella spp. isolates were detected to penicillin (97.5\%) followed by cefalexin $(96.77 \%)$ and amoxicillin $(88.46 \%)$, respectively. The isolates were highly sensitive to gentamicin (94.11\%) (Table 4) (Fig. 1C). Multi-drug resistance to more than 4 antibiotics was found in $91.17 \%$ of Salmonella spp. isolates. Two isolates of Salmonella spp. (6.89\%) from kebab samples were resistant to all tested antibiotics (Table 6).

The highest antibiotic resistance of $S$. aureus isolates was observed against penicillin, amoxicillin, and cephalexin. All of the isolates (100\%) were resistant to the above antibiotics. The sensitivity of isolates was mostly determined to gentamicin (95.45\%). Resistance to gentamicin was found only in one isolate (Table 5) (Fig. 1D). Multi-drug resistance to 7 antibiotics was found in 4 (22.22\%) isolates from kebab and 2 (18.18\%) isolates from hamburger. Overall, $86.20 \%$ of isolates were resistant to $\geq 4$ antibiotics, concurrently (Table 6 ).

\section{Distribution of the antibiotic-resistance genes among the isolated bacterial pathogens}

The prevalence rates of resistance genes in the isolates are presented in Table 7 based on the results of PCR test. The $b l a_{\text {TEM }}$ was the most common resistant gene in the isolates of E. coli (52.54\%) and Salmonella spp. (44.11\%). Fourteen isolates (23.72\%) of E. coli and 10 isolates (29.41\%) of Salmonella spp. were positive for $b l a_{\mathrm{SHV}}$. Also, $55.17 \%$ of $S$. aureus isolates harbored the $m e c \mathrm{~A}$ gene. The $b l a_{\mathrm{Z}}$ was present in two isolates (18.18\%) of $S$. aureus from hamburger samples. Also, this gene was detected in three isolates (16.66\%) from kebab samples. The mecA was observed in 10 isolates (27.27\%) of $L$. monocytogenes.

The electrophoresis pattern of the PCR products of the resistance genes in the bacteria is shown in Figures S1, S2, S3 and S4.

\section{Discussion}

In the present study, the contamination of raw hamburger and kebab to the selected pathogenic bacteria was investigated. Moreover, the antibiotic resistance pattern of the isolates and the presence of the resistance genes were studied. The results of this study exhibited the overall hygienic status of restaurants and fast food centers. Most of the raw kebabs and hamburgers collected from these locations did not have the proper bacteriological quality and high prevalence rates of contamination were observed in the samples to the selected pathogenic bacteria. According to the surveillance report for foodborne disease outbreaks in the United States during 2009-2015, among outbreaks reporting a single location of preparation, restaurants are the most commonly reported locations (2880 outbreaks [61\%]), followed by catering or banquet facilities (636 [14\%]) and private homes (561 [12\%]). Restaurants with sit-down dining (2239 [48\%]) and fast-food restaurants (369 [8\%]) were the most commonly reported types of restaurants [37]. Many foodborne illnesses may occur by the secondary 


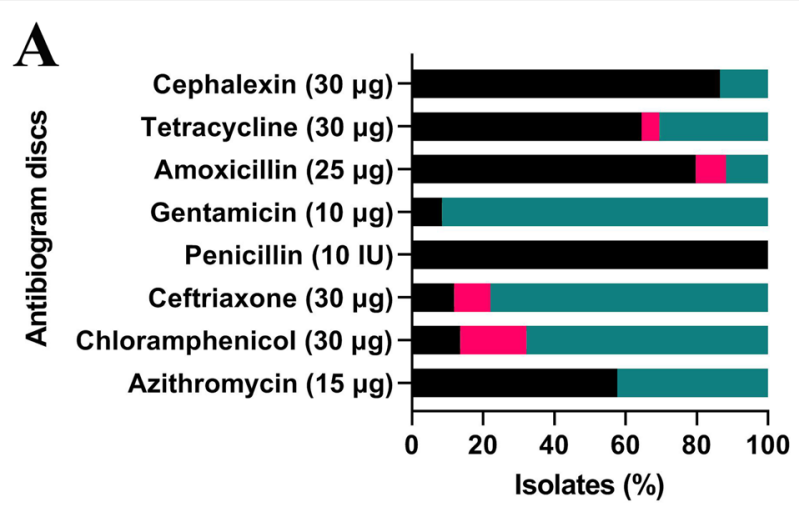

Resistant

Intermediate

Sensitive

Sensitive

Intermediate

Resistant

Sensitive

Intermediate

Resistant

Sensitive

Intermediate

Resistant

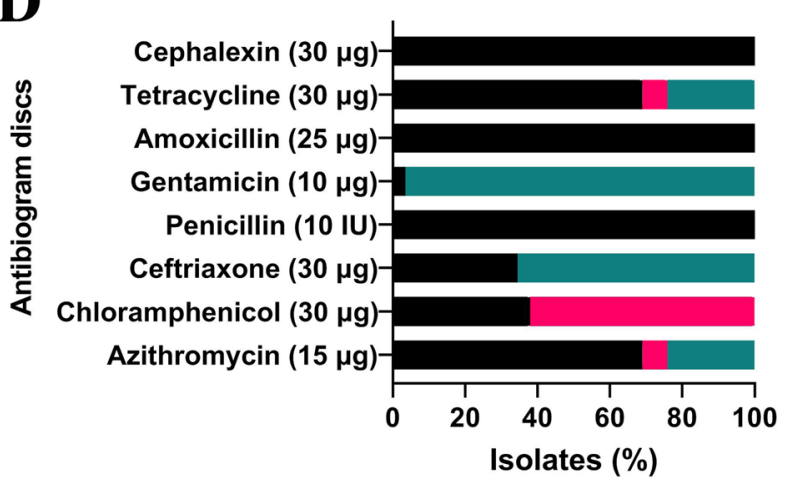

Fig. 1 Antibiotic susceptibility pattern of E. coli (A), L. monocytogenes (B), Salmonella spp. (C) and S. aureus isolates (D) to the evaluated antibiotics 
Table 3 Antibiotic resistance profile of Listeria monocytogenes isolates from raw kebab and hamburger samples

\begin{tabular}{|c|c|c|c|c|c|c|c|c|}
\hline \multirow[t]{2}{*}{ Antibiotic class } & \multirow[t]{2}{*}{ Antibiotics } & \multirow[t]{2}{*}{ Concentration } & \multicolumn{3}{|c|}{$\begin{array}{l}\text { Interpretive categories and zone } \\
\text { diameter breakpoints (nearest } \\
\text { whole } \mathrm{mm})^{\mathrm{a}}\end{array}$} & \multicolumn{3}{|c|}{ No. of isolates/Total isolates } \\
\hline & & & $\mathbf{R}^{\mathbf{b}}$ & $\mathbf{I}$ & $\mathrm{s}$ & $\mathbf{R}$ & 1 & $S$ \\
\hline Macrolides & Azithromycin & $15 \mu g$ & $<17$ & $17-21$ & $\geq 22$ & $24 / 36$ & $7 / 36$ & $5 / 36$ \\
\hline \multirow[t]{2}{*}{ Cephalosporins } & Ceftriaxone & $30 \mu \mathrm{g}$ & $<15$ & $15-20$ & $\geq 21$ & $9 / 36$ & $5 / 36$ & $22 / 36$ \\
\hline & Cephalexin & $30 \mu \mathrm{g}$ & $<12$ & $12-17$ & $\geq 18$ & $34 / 36$ & $2 / 36$ & $0 / 36$ \\
\hline \multirow[t]{2}{*}{ Penicillins } & Penicillin & $101 \mathrm{U}$ & $<8$ & $8-28$ & $\geq 29$ & $36 / 36$ & $0 / 36$ & $0 / 36$ \\
\hline & Amoxicillin & $25 \mu g$ & $<14$ & $14-24$ & $\geq 25$ & $36 / 36$ & $0 / 36$ & $0 / 36$ \\
\hline Aminoglycosides & Gentamicin & $10 \mu \mathrm{g}$ & $<18$ & $18-20$ & $\geq 21$ & $9 / 36$ & $27 / 36$ & $0 / 36$ \\
\hline Tetracyclines & Tetracycline & $30 \mu \mathrm{g}$ & $<22$ & $22-24$ & $\geq 25$ & $31 / 36$ & $5 / 36$ & $0 / 36$ \\
\hline Phenicols & Chloramphenicol & $30 \mu \mathrm{g}$ & $<18$ & $18-20$ & $\geq 21$ & $24 / 36$ & $11 / 36$ & $1 / 36$ \\
\hline
\end{tabular}

a From CLSI [33], Hansen et al. [34], CA-SFM [35]and Soussy et al. [36]

b $R$ resistant, / intermediate, $S$ susceptible

Table 4 Antibiotic resistance profile of Salmonella spp. isolates from raw kebab and hamburger samples

\begin{tabular}{|c|c|c|c|c|c|c|c|c|}
\hline \multirow[t]{2}{*}{ Antibiotic class } & \multirow[t]{2}{*}{ Specific antibiotic tested } & \multirow[t]{2}{*}{ Concentration } & \multicolumn{3}{|c|}{$\begin{array}{l}\text { Interpretive categories and zone } \\
\text { diameter breakpoints (nearest } \\
\text { whole } \mathrm{mm} \text { ) }\end{array}$} & \multicolumn{3}{|c|}{ No. of isolates/Total isolates } \\
\hline & & & $\mathrm{R}^{\mathrm{b}}$ & I & $s$ & $\mathbf{R}$ & 1 & $\mathrm{~s}$ \\
\hline Macrolides & Azithromycin & $15 \mu g$ & $\leq 12$ & - & $\geq 13$ & $22 / 34$ & - & $12 / 34$ \\
\hline \multirow[t]{2}{*}{ Cephalosporins } & Ceftriaxone & $30 \mu \mathrm{g}$ & $\leq 19$ & $20-22$ & $\geq 23$ & $9 / 34$ & $0 / 34$ & $25 / 34$ \\
\hline & Cephalexin & $30 \mu \mathrm{g}$ & $\leq 14$ & - & $\geq 15$ & $33 / 34$ & - & $1 / 34$ \\
\hline \multirow[t]{2}{*}{ Penicillins } & Penicillin & $10 / U$ & $\leq 14$ & - & $\geq 15$ & $33 / 34$ & - & $1 / 34$ \\
\hline & Amoxicillin & $25 \mu g$ & $\leq 13$ & $14-16$ & $\geq 17$ & $30 / 34$ & $0 / 34$ & $4 / 34$ \\
\hline Aminoglycosides & Gentamicin & $10 \mu \mathrm{g}$ & $\leq 12$ & $13-14$ & $\geq 15$ & $2 / 34$ & $0 / 34$ & $32 / 34$ \\
\hline Tetracyclines & Tetracycline & $30 \mu \mathrm{g}$ & $\leq 11$ & $12-14$ & $\geq 15$ & $26 / 34$ & $1 / 34$ & $7 / 34$ \\
\hline Phenicols & Chloramphenicol & $30 \mu \mathrm{g}$ & $\leq 12$ & $13-17$ & $\geq 18$ & $13 / 34$ & $5 / 34$ & $16 / 34$ \\
\hline
\end{tabular}

a From CLSI [32]

${ }^{\mathrm{b}} R$ resistant, I intermediate, $S$ susceptible

Table 5 Antibiotic resistance profile of Staphylococcus aureus isolates from raw kebab and hamburger samples

\begin{tabular}{|c|c|c|c|c|c|c|c|c|}
\hline \multirow[t]{2}{*}{ Antibiotic class } & \multirow[t]{2}{*}{ Specific antibiotic tested } & \multirow[t]{2}{*}{ Concentration } & \multicolumn{3}{|c|}{$\begin{array}{l}\text { Interpretive categories and zone } \\
\text { diameter breakpoints (nearest } \\
\text { whole } \mathrm{mm})^{\mathrm{a}}\end{array}$} & \multicolumn{3}{|c|}{ No. of isolates/Total isolates } \\
\hline & & & $\mathbf{R}^{\mathbf{b}}$ & $\mathbf{I}$ & $\mathrm{s}$ & $\mathbf{R}$ & 1 & S \\
\hline Macrolides & Azithromycin & $15 \mu g$ & $\leq 13$ & $14-17$ & $\geq 18$ & $20 / 29$ & $2 / 29$ & $7 / 29$ \\
\hline \multirow[t]{2}{*}{ Cephalosporins } & Ceftriaxone & $30 \mu g$ & $\leq 13$ & $14-20$ & $\geq 21$ & $10 / 29$ & $0 / 29$ & $19 / 29$ \\
\hline & Cephalexin & $30 \mu g$ & $\leq 21$ & - & $\geq 22$ & $29 / 29$ & - & $0 / 29$ \\
\hline \multirow[t]{2}{*}{ Penicillins } & Penicillin & 1010 & $\leq 28$ & - & $\geq 29$ & $29 / 29$ & - & $0 / 29$ \\
\hline & Amoxicillin & $25 \mu g$ & $\leq 28$ & - & $\geq 29$ & $29 / 29$ & - & $0 / 29$ \\
\hline Aminoglycosides & Gentamicin & $10 \mu g$ & $\leq 12$ & $13-14$ & $\geq 15$ & $1 / 29$ & $0 / 29$ & $28 / 29$ \\
\hline Tetracyclines & Tetracycline & $30 \mu g$ & $\leq 14$ & $15-18$ & $\geq 19$ & $20 / 29$ & $2 / 29$ & $7 / 29$ \\
\hline Phenicols & Chloramphenicol & $30 \mu g$ & $\leq 12$ & $13-17$ & $\geq 18$ & $11 / 29$ & $18 / 29$ & $0 / 29$ \\
\hline
\end{tabular}

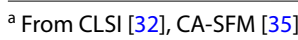

${ }^{b} R$ resistant, $/$ intermediate, $S$ susceptible 
Table 6 Prevalence of multi-drug resistance in the selected foodborne pathogens isolated from raw kebab and hamburger samples

\begin{tabular}{|c|c|c|c|c|}
\hline Food borne pathogens & No. of antibiotics & $\begin{array}{l}\text { Overall } \\
n=59 \text { (\%) }\end{array}$ & $\begin{array}{l}\text { Kebab } \\
n=35 \text { (\%) }\end{array}$ & $\begin{array}{l}\text { Hamburger } \\
n=24(\%)\end{array}$ \\
\hline \multirow[t]{9}{*}{ Escherichia coli } & 1 & $0(0.00)$ & $0(0.00)$ & $0(0.00)$ \\
\hline & 2 & $3(5.08)$ & $2(5.71)$ & $1(4.16)$ \\
\hline & 3 & $16(27.11)$ & $11(31.42)$ & $5(20.83)$ \\
\hline & 4 & $14(23.72)$ & $12(34.28)$ & $2(8.33)$ \\
\hline & 5 & $7(11.86)$ & $7(20.00)$ & $0(0.00)$ \\
\hline & 6 & $9(15.25)$ & $3(8.57)$ & $6(25.00)$ \\
\hline & 7 & $7(11.86)$ & $0(0.00)$ & $7(29.16)$ \\
\hline & 8 & $3(5.08)$ & $0(0.00)$ & $3(12.50)$ \\
\hline & & $\begin{array}{l}\text { Overall } \\
n=36(\%)\end{array}$ & $\begin{array}{l}\text { Kebab } \\
n=25 \text { (\%) }\end{array}$ & $\begin{array}{l}\text { Hamburger } \\
n=11(\%)\end{array}$ \\
\hline \multirow[t]{9}{*}{ Listeria monocytogenes } & 1 & $0(0.00)$ & $0(0.00)$ & $0(0.00)$ \\
\hline & 2 & $1(2.77)$ & $0(0.00)$ & $1(9.09)$ \\
\hline & 3 & $4(11.11)$ & $3(12.00)$ & $1(9.09)$ \\
\hline & 4 & $2(5.55)$ & $1(4.00)$ & $1(9.09)$ \\
\hline & 5 & $6(16.66)$ & $5(20.00)$ & $1(9.09)$ \\
\hline & 6 & $15(42.66)$ & $12(48.00)$ & $3(27.27)$ \\
\hline & 7 & $5(13.88)$ & $3(12.00)$ & $2(18.18)$ \\
\hline & 8 & $3(8.33)$ & $1(4.00)$ & $2(18.18)$ \\
\hline & & $\begin{array}{l}\text { Overall } \\
n=34 \text { (\%) }\end{array}$ & $\begin{array}{l}\text { Kebab } \\
n=29 \text { (\%) }\end{array}$ & $\begin{array}{l}\text { Hamburger } \\
n=5(\%)\end{array}$ \\
\hline \multirow[t]{9}{*}{ Salmonella spp. } & 1 & $1(2.94)$ & $1(3.44)$ & $0(0.00)$ \\
\hline & 2 & $1(2.94)$ & $1(3.44)$ & $0(0.00)$ \\
\hline & 3 & $1(2.94)$ & $1(3.44)$ & $0(0.00)$ \\
\hline & 4 & $9(26.47)$ & $7(24.13)$ & $2(40.00)$ \\
\hline & 5 & $8(23.52)$ & $5(17.24)$ & $3(60.00)$ \\
\hline & 6 & $10(29.41)$ & $10(34.48)$ & $0(0.00)$ \\
\hline & 7 & $2(5.88)$ & $2(6.89)$ & $0(0.00)$ \\
\hline & 8 & $2(5.88)$ & $2(6.89)$ & $0(0.00)$ \\
\hline & No. of antibiotics & $\begin{array}{l}\text { Overall } \\
n=29 \text { (\%) }\end{array}$ & $\begin{array}{l}\text { Kebab } \\
n=18 \text { (\%) }\end{array}$ & $\begin{array}{l}\text { Hamburger } \\
n=11(\%)\end{array}$ \\
\hline \multirow[t]{8}{*}{ Staphylococcus aureus } & 1 & $0(0.00)$ & $0(0.00)$ & $0(0.00)$ \\
\hline & 2 & $0(0.00)$ & $0(0.00)$ & $0(0.00)$ \\
\hline & 3 & $4(13.79)$ & $1(5.55)$ & $3(27.27)$ \\
\hline & 4 & $7(24.13)$ & $5(27.77)$ & $2(18.18)$ \\
\hline & 5 & $4(13.79)$ & $3(16.66)$ & $1(9.09)$ \\
\hline & 6 & $8(27.58)$ & $5(6.25)$ & $3(27.27)$ \\
\hline & 7 & $6(20.68)$ & $4(22.22)$ & $2(18.18)$ \\
\hline & 8 & $0(0.00)$ & $0(0.00)$ & $0(0.00)$ \\
\hline
\end{tabular}

contamination of food and improper implementation of hygienic principles [38]. The results of the present study showed that raw kebabs and hamburgers prepared in restaurants and fast food centers could be a potential risk factor for public health.

Since microbial contamination in large numbers may cause rapid alterations in the organoleptic properties of the meat products; TBC is used as a common criterion to predict the shelf life of these products. Also,
TBC is an expression of the hygienic quality level of foodstuffs [4]. According to European Union standards, the microbiological limit for $\mathrm{TBC}$ in meat preparations is $6.7 \log \mathrm{CFU} / \mathrm{g}$ [39]. Also, based on the GMP guidelines, it has been recommended that the TBC level for raw meat preparations should not exceed 5 (maximum 7) $\log \mathrm{CFU} / \mathrm{g}[40,41]$. In the present study, the mean value for TBC in raw kebab samples was higher than $6.7 \log \mathrm{CFU} / \mathrm{g}$. Also, the mean levels of TBC in all 
Table 7 Prevalence of antibiotic-resistance genes in the selected foodborne bacterial isolated from kebab and hamburger samples

\begin{tabular}{|c|c|c|c|c|c|}
\hline \multirow[t]{2}{*}{ Pathogenic bacteria } & & \multicolumn{4}{|c|}{ No. of positive samples for target genes } \\
\hline & & $b l a_{\mathrm{SHV}}$ & $b l a_{\mathrm{z}}$ & $b l a_{\mathrm{TEM}}$ & mecA \\
\hline \multirow[t]{3}{*}{ E. coli } & $\begin{array}{l}\text { Overall } \\
n=59\end{array}$ & $14(23.72 \%)$ & $-a^{a}$ & $31(52.54 \%)$ & - \\
\hline & $\begin{array}{l}\text { Kebab } \\
n=35\end{array}$ & $7(20.00 \%)$ & - & $18(51.42 \%)$ & - \\
\hline & $\begin{array}{l}\text { Hamburger } \\
n=24\end{array}$ & $7(29.16 \%)$ & - & $13(54.16 \%)$ & - \\
\hline \multirow[t]{3}{*}{ Salmonella spp. } & $\begin{array}{l}\text { Overall } \\
n=34\end{array}$ & $10(29.41 \%)$ & - & $15(44.11 \%)$ & - \\
\hline & $\begin{array}{l}\text { Kebab } \\
n=29\end{array}$ & $8(27.58 \%)$ & - & $12(41.37 \%)$ & - \\
\hline & $\begin{array}{l}\text { Hamburger } \\
n=5\end{array}$ & $2(40.00 \%)$ & - & $3(60.00 \%)$ & - \\
\hline \multirow[t]{3}{*}{ L. monocytogenes } & $\begin{array}{l}\text { Overall } \\
n=36\end{array}$ & - & - & - & $10(27.27 \%)$ \\
\hline & $\begin{array}{l}\text { Kebab } \\
n=25\end{array}$ & - & - & - & $8(32.00 \%)$ \\
\hline & $\begin{array}{l}\text { Hamburger } \\
n=11\end{array}$ & - & - & - & $2(18.18 \%)$ \\
\hline \multirow[t]{3}{*}{ S. aureus } & $\begin{array}{l}\text { Overall } \\
n=29\end{array}$ & - & $5(17.24 \%)$ & - & $16(55.17 \%)$ \\
\hline & $\begin{array}{l}\text { Kebab } \\
n=18\end{array}$ & - & $3(16.66 \%)$ & - & $10(55.55 \%)$ \\
\hline & $\begin{array}{l}\text { Hamburger } \\
n=11\end{array}$ & - & $2(18.18 \%)$ & - & $6(54.54 \%)$ \\
\hline
\end{tabular}

${ }^{\text {a Not detected }}$

samples exceed $5 \log \mathrm{CFU} / \mathrm{g}$. The high levels of TBC in this study are in agreement with the results of previous studies $[4,42,43]$. The high levels of microbial contamination in meat products may occur as the result of high contamination levels of raw materials and inappropriate processing conditions. Besides the microbial contamination of meat, the used spices, and other additives, the hygienic conditions of the processing environment, equipment, and handlers have significant effects on the TBC levels of meat products [4].

Since E. coli is known as a fecal indicator of RTE products [44], contamination of hamburger and kebab samples to this bacterium may cause foodborne disease in consumers.

In comparison with the results of the present study, lower contamination levels to E. coli have been reported in hamburger samples in Portugal (20\%) [17] and beef samples in Saudi Arabia (22.22\%) [45] and Ethiopia (6\%) [46]. However, other authors reported the rates of $88.0 \%$ in beef samples in Ghana [1] and $100 \%$ of Beef preparations (meatballs, minced meat, hamburgers, white sausages, and red sausages) in the northwest of Spain [4]. Regarding the results of the present study, high levels of contamination to $E$. coli in RTE meat products may be due to the high contamination of the raw materials or preparation of products in an unhygienic condition.

In the present study, all hemolytic isolates and all isolates that were positive for $s t x 1$, st $x 2$, or eae genes were considered as potential pathogenic E. coli. In kebab samples, 6 potential pathogenic E. coli isolates were detected (prevalence 12.0\%). Of these 6 isolates, four isolates were categorized as Shiga toxin-producing strain (STEC) (8.0\%). In hamburger samples, 4 potential pathogenic $E$. coli could be identified (prevalence $8.0 \%$ ); of these, one was classified as STEC (2.0\%).

$E$. coli is one of the most important pathogenic bacteria in nosocomial infections. It is known as the most important cause of endemic and epidemic diarrhea in the world [24, 25, 47-49]. Although the human gut flora is composed of a large number of bacterial species, $E$. coli exhibits greater antibiotic resistance than other Enterobacteriaceae, and this problem has been increased in both developed and developing countries [50]. The antibiotic-resistance strains of $E$. coli can be transmitted between animals and humans through the food chain. They can also transfer their resistance genes to other pathogens [51].

In agreement with the results of the present study, Hemeg [45] found that E. coli isolates from beef meat 
samples were highly resistant to penicillin (100\%) and amoxicillin-clavulanic acid (100\%). All amoxicillin-clavulanic acid-resistant $E$. coli isolates were positive for the $b l a_{\mathrm{TEM}}$ gene. Moreover, $b l a_{\mathrm{SHV}}$ resistant gene was detected in $60.52 \%$ of isolate. Also, Alegría et al. [52] in a study about the presence of $\beta$-lactam-resistant $E$. coli in food samples, reported that 80 and $20 \%$ of isolates carried $b l a_{\mathrm{TEM}}$ and $b l a_{\mathrm{SHV}}$ genes, respectively. Similar to the results of the present study, Ramadan et al. [53] reported that the highest resistance of $E$. coli isolates from different resources including retail ground beef in Mansoura, Egypt was to ampicillin. A high rate of resistance to amoxicillin and penicillin in the present study may be associated with the role of $b l a_{\mathrm{SHV}}$ and $b l a_{\mathrm{TEM}}$ genes in the antibiotic resistance of $E$. coli. It has been reported that TEM and SHV extended-spectrum beta-lactamases are responsible for the resistance against ampicillin, carbenicillin, cephalothin, and extended-spectrum cephalosporins [54].

The $b l a_{\mathrm{TEM}}$ gene was the most common resistance gene in $E$. coli isolates in this study. However, only $77.41 \%$ of the resistance isolates to both amoxicillin and penicillin harbored this resistance gene. Also, $57.14 \%$ of isolates positive for $b l a_{\mathrm{SHV}}$ showed resistance to cephalexin, penicillin, and amoxicillin in phenotypic experiments. It has been reported that the E. coli strains that are phenotypically positive for ESBL production but genotypically negative for ESBL genes can also be regarded as ESBL producers. Because most of the phenotypically-positive isolates do not harbor all existing resistance genes [55].

Listeria monocytogenes is a foodborne pathogen that is responsible for a disease in humans and animals, called listeriosis. In healthy people, it can cause febrile gastroenteritis with influenza-like symptoms. However, an acute disease may occur with the symptoms of encephalitis, meningitis, and septicemia in newborns, pregnant women, and immunocompromised and elderly people with a high rate of mortality $(20-30 \%)$. This organism can be transmitted to human through the consumption of meat, dairy, poultry, fish, and vegetable products $[26,28,56]$. The results of the present study showed that $22.0 \%$ of the raw hamburger samples were contaminated with $L$. monocytogenes. Similar prevalence rates have been reported in retail raw meat products in other countries. In a study conducted in Italy, L. monocytogenes was detected in $23.6 \%$ of raw meat samples [57]. However, lower prevalence rates have been reported by some authors. In Turkey, Doğruer et al. [28] found that 1.25, 7.5 , and $5 \%$ of meat pieces, minced meat, and hamburger samples were positive for L. monocytogenes. Ozbey et al. [58] in a study on raw hamburger meatballs and chicken burgers obtained from different fast food and markets in eastern Turkey found that $5.7 \%$ of hamburger meatballs were positive for L. monocytogenes. However, this organism was isolated from $13.9 \%$ of chicken burgers. The prevalence of L. monocytogenes in RTE meat products collected from seven regions in China was detected only $0.64 \%$ [59].

In agreement with the results of the present study, Nemati et al. [60] in a study on retail RTE meat products in Gorgan province, Iran, reported that most isolates of L. monocytogenes were resistant to penicillin and ampicillin. Wan et al. [61] found that the resistant rates of $L$. monocytogenes strains in China to tetracycline and chloramphenicol were 50.25 and $0.49 \%$, respectively. However, in the present study, higher rates of resistance were observed to tetracycline (86.11\%) and chloramphenicol (66.66\%) in L. monocytogenes isolates.

Different results have been reported about the presence of the mecA gene in L. monocytogenes isolates by other authors. In a study on antibiotic resistance profiles of $L$. monocytogenes isolated from chicken meat in Fukuoka (Japan) in 2017, 94.7\% of isolates were positive for mecA [56]. However, Wang et al. [61] reported that all experimental strains of foodborne listeria were negative for this gene. The mecA gene encodes a penicillin-binding protein [56], which is probably involved in the high resistance of all $L$. monocytogenes isolates to penicillin in this study. However, only $25.00 \%$ of them harbored the mecA gene. This result indicates that other genes may also be involved in the resistance of isolates to penicillin.

Salmonella spp. is known as the most important zoonotic foodborne pathogens after the campylobacter. Chicken, turkey, pork, beef, and other meats as well as eggs are the most important sources of this pathogen [62]. The intact tissues of healthy animals are sterile. However, after the slaughtering of these animals, the surface of the meat can be contaminated with these bacteria by the animal skin, the contents of the lumen, or handling. Therefore, observation of the hygienic principles is necessary during the slaughter of livestock and the preparation of the meat product $[63,64]$. Salmonella spp. are sensitive organisms to heating processes. So, enough heat can kill this bacterium during food cooking. Meat can be a potential source of salmonellosis for the consumers, if it has primary contamination or is secondarily contaminated during the preparation or the use of additives, and it is not given enough heat during the cooking process [63]. Since kebab and hamburger can be prepared by hands from red meat, the cooking heat is not possibly enough to eliminate the primary or secondary contamination.

Taghizadeh et al. [65] reported that the prevalence of Salmonella spp. in hamburger samples in Mazandaran province (Iran) was $48.18 \%$. In another study in Mexico, Salmonella spp. was determined in ground beef (56.7\%). 
However, in the present study, Salmonella spp. was detected in $10 \%$ of hamburger samples. The probable reason for lower contamination levels of hamburger samples than kebabs could be related to the fact that raw hamburgers are usually kept in freezers in restaurants and fast-food centers, while raw kebab samples were stored in the refrigerator.

Antibiotics are necessary to treat Salmonella-induced enteritis particularly when there is a risk of acute infection (e.g. for infants, elderly and immunocompromised individuals) [66].

Nowadays, due to increased antibiotic resistance of Salmonella strains, fluoroquinolones and third-generation cephalosporins are usually used in the treatment of Salmonella infections. Other Antibiotics such as ampicillin, chloramphenicol, and cotrimoxazole, which were once the most widely used in the treatment of these infections, are less commonly used in recent years [67, 68]. In the present study, Salmonella spp. isolates had high resistance rates to penicillin, cephalexin, amoxicillin, and tetracycline. Also, six isolates (17.64\%) with multidrug resistance to penicillin, amoxicillin, and cephalexin in the phenotypic study, harbored both $b l a_{\mathrm{TEM}}$ and $b l a_{\mathrm{SHV}}$ genes.

Similar to the findings of this study, high rates of antibiotic resistance in Salmonella spp. isolates to penicillins, tetracyclines, and cephalosporins have been reported by other authors. Altaf Hussain et al. [20] found that Salmonella isolates from retail raw beef in Karachi city, Pakistan were highly resistant to ampicillin (90.5\%), amoxicillin (81.1\%), and tetracycline (76\%). Fortuna et al. [69] found that the Salmonella spp. isolated from beef and chicken hamburgers, were resistant to cefotaxime (88.89\%), ampicillin (71.11\%), cephalothin (68.89\%), ceftriaxone (53.33\%), cefoxitin (48.89\%), and ceftazidime (42.22\%). In the other study about chicken and beef meat samples as well as internal organs in northern Egypt, the resistance of Salmonella enterica serovars to ampicillin, cefotaxime, cefpodoxime, and tetracycline were 86.7, 80.0, 60.0, and $40.0 \%$, respectively [70]. The results of previous studies were in agreement with the findings of the present work about the presence of bla $a_{\mathrm{TEM}}$ and $b l a_{\mathrm{SHV}}$ in Salmonella spp. isolates. Moawad et al. [70] detected $b l a_{\mathrm{TEM}}$ in $73.3 \%$ of Salmonella isolates from chicken and beef meat samples in northern Egypt. The presence of $b l a_{\text {TEM }}$ was also reported in $17 \%$ of Salmonella isolates from retail meats in Alberta, Canada, while $b l a_{\mathrm{SHV}}$ was not detected in the isolates [71]. In a study on retail raw beef in Karachi city, Pakistan, it was reported that $b l a_{\text {TEM }}$ were the dominant resistant genes in SalmonellaEnteritidis ( $S$. Enteritidis) (24.0\%) and SalmonellaTyphimurium (S. Typhimurium) (14.5\%) followed by Salmonella Pullorum (S. Pullorum) (2\%) whereas $b l a_{\mathrm{SHV}}$ was the least detected $\beta$-lactamase gene in isolates of $S$. Enteritidis (2.6\%), $S$. Typhimurium (5\%) and S. Pullorum (2\%) [20].

Due to the wide use of raw meat in the preparation of hamburgers and kebab as well as the increasing interest in the use of RTE foods, there is a possibility for the contamination of these products with $S$. aureus resulting in foodborne intoxication in the consumers. Contamination of RTE foods to $S$. aureus may be due to a variety of reasons, including a lack of proper hygiene during the preparation [72]. Aycicek et al. [73] reported that food handlers play a major role in S. aureus contamination of ready-to-eat products.

The results of previous studies about the contamination of hamburger and meat products with $S$. aureus are in agreement with the finding of the present study. The prevalence rates of $S$. aureus in hamburger samples have been reported to be $25 \%$ in Tehran (Iran) [74] and 20\% in Poland [75]. In a meta-analysis study in Ethiopia, the prevalence rates of Staphylococcus spp. in beef and other animal meats were 21 and 22\%, respectively [46]. Arafa et al. [76] in a study in Cairo (Egypt) found that $30 \%$ of minced beef meat samples and $10 \%$ of beef burger samples were positive for $S$. aureus.

Many authors have reported the high resistance level of $S$. aureus isolates to penicillins and tetracyclines that are in agreement with the results of the antimicrobial susceptibility test in the present study. Çetinkaya and Elal Mus [77] reported that the $S$. aureus isolates from different foodstuffs including raw meatballs in Turkey were resistant to penicillin (62.9\%) and ampicillin (59.3\%). Resistant of $S$. aureus isolates (57.14\%) from the beef burger and beef minced meat to penicillin and methicillin has also been reported in Cairo, Egypt [76]. In a similar study on raw retail meat samples collected from Isfahan province, Iran, $S$. aureus isolates exhibited the highest resistance to tetracycline $(79.16 \%)$, penicillin (72.91\%), and doxycycline (41.66\%) [78].

The $m e c \mathrm{~A}$ and $b l a_{\mathrm{Z}}$ genes are common genes involved in antibiotic resistance of $S$. aureus strains. In the study of Shahraz et al. [74] and Chajęcka-Wierzchowska et al. [75] on hamburgers samples, the mecA gene was detected in $100 \%$ of the Methicillin-resistant S. aureus isolates. Arafa et al. [76] also reported the presence of the mecA and blaZ gene in $85.7 \%$ of $S$. aureus isolates from minced beef meat and burger samples, while all of the isolates $(100 \%)$ were positive for the $b l a_{\mathrm{z}}$ gene. In the study of Baghbaderani et al. [78], the $b l a_{\mathrm{Z}}$ gene was detected in $58.33 \%$ of the isolates from raw retail meat samples. In the present study, these genes were detected in the $S$. aureus isolates from hamburger and kebab samples. Notably, all of the resistance isolates to penicillin, amoxicillin, and cephalexin in the phenotypic tests, harbored both mecA and $b l a_{\mathrm{Z}}$ genes. Penicillin is usually used as 
the drug of choice for the treatment of infections caused by $S$. aureus. However, it has been recently reported that approximately $90 \%$ of human $S$. aureus are resistant to penicillin. The blaZ gene has been suggested as the main mechanism responsible for penicillin resistance in Staphylococci. Also, the blaZ gene can transfer between coagulase-negative Staphylococci (as the resistance gene reservoir) and $S$. aureus. Moreover, the production of penicillin-binding protein, $\mathrm{PBP} 2 \mathrm{a}$, encoded by mecA is proposed as the second primary mechanism for penicillin resistance particularly in the human isolates [79].

In this study, it was observed that the phenotypic resistance pattern was different from the presence of associated resistance genes in the isolates. For example, resistance to penicillins in the phenotypic study was more prevalent than the related resistance genes in the isolates. These results indicate that possession of a certain phenotypic resistance pattern does not always accurately correlate with a resistance gene. While the antibiotic resistance genes may be mutated or not expressed, other mechanisms of resistance such as multidrug efflux pumps, mutations in outer membrane porins, or other unknown resistance genes may be effective in the phenotypic resistance pattern $[80,81]$.

In the present study, high resistance levels and multidrug resistances against up to eight antibiotics were observed in the isolates, with a high proportion for $\beta$-lactams. Since beta-lactams are the most commonly used antibiotics in human and veterinary medicine, the emergence of $\beta$-lactam-resistant pathogenic bacteria can be a big challenge for public health [82].

\section{Conclusion}

The findings of this study showed that kebab and hamburger, as the widely consumed RTE meat products, have a high prevalence of important foodborne pathogens showing multi-resistance to most commonly used antibiotics of therapeutic importance in human medicine. Although kebab and hamburger are usually not consumed in raw form, consumption of improperly cooked products and possible cross-contamination to other foodstuffs can pose a major potential risk to public health. The discrepancies between the phenotypic resistances and associated resistance genes in the isolates indicated that possession of a certain phenotypic resistance pattern may be related to other resistance mechanisms.

The present study highlights the urgent need for precise observation of hygienic principles by food handlers, appropriate authority supervision, and regulatory monitoring to ensure that safe RTE meat products are prepared for the consumers. To better understand the epidemiology of antibiotic resistance in foodborne pathogens, further studies should be focused on other RTE foods and their potential risk for transmission of multidrug resistance pathogens. Also, it is suggested that in future studies, serotyping assays be performed on the isolates to identify the common serovars of pathogenic bacteria with antibiotic resistant in RTE meat products.

\section{Methods \\ Sampling}

A total of 100 samples of kebab and hamburger (50 samples, each) were collected from restaurants and fast food centers in Tabriz city, Iran from May 2018 to September 2019. The samples were transported immediately to the laboratory and kept under refrigeration $\left(4 \pm 1{ }^{\circ} \mathrm{C}\right)$. The study was conducted in the laboratory of Food microbiology in the Faculty of Veterinary Medicine, University of Tabriz.

\section{Total bacterial count}

Briefly, $25 \mathrm{~g}$ of the kebab or hamburger samples were placed in a sterile Pulsifer bag containing $225 \mathrm{~mL}$ of $0.1 \%$ sterile peptone water [83]. The contents of the bags were homogenized for $2 \mathrm{~min}$ using the Pulsifier (Microgen Bioproducts, Surrey, UK). Decimal dilutions of homogenate samples were prepared in test tubes containing $9 \mathrm{ml}$ of $0.1 \%$ peptone water. One (1) $\mathrm{ml}$ of each dilution was pour plated on plate count agar (Merck, Darmstadt, Germany). The plates were incubated at $37^{\circ} \mathrm{C}$ for $48 \mathrm{~h}$, and the colony counts were calculated [84].

\section{Isolation and identification of pathogenic bacteria Escherichia coli}

Isolation of E. coli was performed according to the FDA method [85] and Ombarak et al. [86]. Briefly, E. coli was identified in the samples using Lauryl tryptose (LST) broth (Merck, Germany) containing Durham tube. After incubation at $37^{\circ} \mathrm{C}$ for $48 \mathrm{~h}, 1 \mathrm{ml}$ of the bacterial suspension from positive tubes (determined by turbidity and gas production) was transferred to the brilliant green bile lactose broth (BGLB) (Merck, Germany) and incubated at $37^{\circ} \mathrm{C}$ for $48 \mathrm{~h}$. Aliquot of suspension $(0.1 \mathrm{ml})$ from positive tubes were streaked on the Eosin Methylene Blue (EMB) agar plates and incubated at $37^{\circ} \mathrm{C}$ for $24 \mathrm{~h}$. The presumptive colonies (dark centered and flat colonies with metallic green sheen) were was picked and streaked on tryptic soy agar (TSA) (Merck, Germany), and incubated at $37^{\circ} \mathrm{C}$ for $24 \mathrm{~h}$. The colonies were cultured on the slants of nutrient agar at $37^{\circ} \mathrm{C}$ for $16 \mathrm{~h}$ and used for biochemical analysis. The isolates were confirmed by Gram staining, growth on MacConkey Agar (Merck, Darmstadt, Germany), growth in brilliant green bile lactose broth (Merck, Darmstadt, Germany), and biochemical tests such as IMViC, oxidase, catalase, motility tests, sugar fermentation and nitrate reduction (Table 
S1) $[1,87]$. Finally, the isolates of pathogenic E. coli were detected after hemolysis test on enterohemolysin agar (Oxoid, Germany) as well as PCR test for the presence of stx1 (primers forward: 5'-GTGGTTGCGAAGGAA TTTACC-3'; reverse: 5'-ACTGATCCCTGCAACACG CTG-3'), stx2 (forward: $5^{\prime}$-ATCCTATTCCCGGGAGTT TACG; reverse: 5'-GCGTCATCGTATACACAGGAGC$3^{\prime}$ ) and eae (intimin) (forward: 5'-ATGCCCGGACCC GGCACAAG-3'; reverse: 5'-AAGAGTCTCGCCAGT ATTCG-3') genes [88].

\section{Listeria monocytogenes}

Isolation and identification of $L$. monocytogenes were carried out using the method of Food and Drug Administration (FDA) [83]. Briefly, 25 g of each sample was mixed with $225 \mathrm{ml}$ of Listeria enrichment broth (Merck, Darmstadt, Germany). The cultures were incubated at $30^{\circ} \mathrm{C}$ for $4 \mathrm{~h}$ for the enrichment. Then, Listeria-Selective Enrichment Supplement (Merck, Darmstadt, Germany) was added to the broth and incubated for $44 \mathrm{~h}$. A loopful from the enrichment broth was streaked onto Palcam Listeria Selective agar (Merck, Darmstadt, Germany) and incubated for $48 \mathrm{~h}$ at $35^{\circ} \mathrm{C}$. The grey-green colonies with a black center and black halo were subjected to the confirmatory tests such as Gram staining, motility in SIM Medium and biochemical test (catalase, oxidase, hemolysis on blood agar, urea, nitrate reduction, MR-VP, CAMP test, esculin hydrolysis, and fermentation of glucose, mannitol, maltose, xylose, and rhamnose) (Table S1) [83].

\section{Salmonella spp.}

Isolation of Salmonella spp. was firstly performed by pre-enrichment of samples in lactose broth (Merck, Darmstadt, Germany) at $37^{\circ} \mathrm{C}$ for $24 \mathrm{~h}$. For selective enrichment, pre-enriched cultures were transferred into Selenite Cystine (SC) broth (Merck, Darmstadt, Germany) and Tetrathionate Brilliant Green bile (TBG) broth (Merck, Darmstadt, Germany), and incubated at $35^{\circ} \mathrm{C}$ for $24 \mathrm{~h}$. Then, these cultures were streaked onto Bismuth Sulphite agar (BSA) (Oxoid, Basingstoke, UK), Xylose Lysine Deoxycholate Agar (XLD) (Oxoid, Basingstoke, UK), and Hektoen Enteric agar (HEA) (Oxoid, Basingstoke, UK) as selective media and incubated at $35^{\circ} \mathrm{C}$ for $48 \mathrm{~h}$. Typical colonies were cultured on the slants of Tryptic soy agar (TSA) (Merck, Darmstadt, Germany) and subjected to biochemical tests using Lysine Iron agar (LIA) (Merck, Darmstadt, Germany), Triple Sugar Iron (TSI) agar (Merck, Darmstadt, Germany), Sulfide-IndoleMotility (SIM) medium (Merck, Darmstadt, Germany), and Christensen's Urea agar (Merck, Darmstadt, Germany) (Table S1) [89].

\section{Staphylococcus aureus}

One (1) $\mathrm{ml}$ of sample solution was taken to CookedMeat broth (Merck, Germany) containing $10 \% \mathrm{NaCl}$ and incubated at $37^{\circ} \mathrm{C}$ for $24 \mathrm{~h}$. Then, a loopful of culture was transferred onto Baird-Parker agar (Merck, Darmstadt, Germany) supplemented with egg yolk and tellurite emulsion $(50 \mathrm{ml} / \mathrm{l})$, and incubated at $37^{\circ} \mathrm{C}$ for $24 \mathrm{~h}$. Black shiny colonies surrounded by clear halo were confirmed by Gram staining and biochemical tests such as catalase activity, hemolytic activity on blood agar (Merck, Darmstadt, Germany), VP, urease, oxidation activity, fermentation of mannitol on Mannitol salt agar (Merck, Darmstadt, Germany), production of coagulase, and DNase test (Table S1) [74, 78].

\section{Antimicrobial susceptibility test}

The antimicrobial susceptibility test was performed by the Kirby-Bauer disk diffusion method [90] according to the guidelines of clinical laboratory standards Institute (CLSI) [32]. Based on the interpretive categories and zone diameter breakpoints (nearest whole $\mathrm{mm}$ ) given by CLSI, the inhibition zone diameter was measured and interpreted as resistant, intermediate, and susceptible. Duplicate isolates were excluded from the study based on isolation rank (time criterion). Using this criterion, the first isolate of a particular species isolated from a single sample during the study period was included in the analysis [91]. The isolates were tested against azithromycin $(15 \mu \mathrm{g})$, chloramphenicol $(30 \mu \mathrm{g})$, amoxicillin $(25 \mu \mathrm{g})$, gentamicin $(10 \mu \mathrm{g})$, penicillin (10 IU), ceftriaxone $(30 \mu \mathrm{g})$, cephalexin $(30 \mu \mathrm{g})$, and tetracycline $(30 \mu \mathrm{g})$ (Patan-Teb Company, Iran). The selected antimicrobials were representative of the major classes of antimicrobial drugs commonly used in veterinary and human medicine. The isolates were inoculated in Trypticase Soy Broth (TSB) (Merck, Darmstadt, Germany) at $37^{\circ} \mathrm{C}$ for $18 \mathrm{~h}$. The turbidity of microbial suspension was adjusted to 0.5 McFarland standard using sterile TSB. The isolates were cultured separately on Müller-Hinton agar (Merck, Darmstadt, Germany). The antibiotic discs were placed on the agar (with intervals of $3 \mathrm{~cm}$ ) and incubated at $37^{\circ} \mathrm{C}$ for $24 \mathrm{~h}$. The zones of growth inhibition were measured and the results were presented according to the guidelines of CLSI [32].

\section{PCR assays \\ DNA extraction}

Firstly, L. monocytogenes and S. aureus isolates were cultured on the blood agar (Merck, Darmstadt, Germany). Salmonella spp. and E. coli were grown on MacConkey agar. Typical colonies were transferred to the nutrient broth and incubated at $37^{\circ} \mathrm{C}$ for $24 \mathrm{~h}$. The bacterial 
DNA was extracted by the boiling method. Briefly, bacteria grown in the broth were suspended in $300 \mu \mathrm{L}$ of deionized water. The suspension was heated at $100^{\circ} \mathrm{C}$ for $10 \mathrm{~min}$ in a water bath followed by cooling in an ice bath for $5-10 \mathrm{~min}$. Then, it was centrifuged at $13000 \times \mathrm{g}$ for $5 \mathrm{~min}$. Finally, the supernatant containing the bacterial DNA was transferred to a sterile microtube and used as the DNA template. The templates were stored at $-20^{\circ} \mathrm{C}$ until the next stages of PCR analysis [92].

\section{PCR-based detection of the antibiotic-resistance genes among the isolated bacterial pathogens}

The isolates were tested for antibiotic-resistance genes of $b l a_{\mathrm{TEM}}, b l a_{\mathrm{SHV}}, b l a_{\mathrm{Z}}$, and $m e c \mathrm{~A}$ using the specific primers (Table 8). Firstly, $5.5 \mu \mathrm{L}$ of deionized water was added to $3 \mu \mathrm{L}$ of template DNA in a microtube. Then, $1 \mu \mathrm{L}$ of each primer (Forward and Reverse), was added to the solution. Finally, $12.5 \mu \mathrm{L}$ of RED-Extract-N-Amp master mix $2 \times$ (containing buffer, salts, dNTPs, Taq polymerase, REDTaq dye, and JumpStart Taq antibody) (Sigma-Aldrich, USA) was added. The mixture was then put in the thermocycler (MWG AC Biotech Thermal Cycler, USA). The PCR condition for $m e c \mathrm{~A}$ and $b l a_{\mathrm{Z}}$ were as follows: initial denaturation at $94^{\circ} \mathrm{C}$ for $2 \mathrm{~min}, 30$ cycles of denaturation at $94^{\circ} \mathrm{C}$ for $1 \mathrm{~min}$, annealing at $55^{\circ} \mathrm{C}$ for $1 \mathrm{~min}$, the extension at $72{ }^{\circ} \mathrm{C}$ for $2 \mathrm{~min}$ and the final extension at $72^{\circ} \mathrm{C}$ for $5 \mathrm{~min}$. The PCR condition for $b l a_{\mathrm{TEM}}$ and $b l a_{\mathrm{SHV}}$ were as follows: initial denaturation at $94^{\circ} \mathrm{C}$ for $5 \mathrm{~min}, 32$ cycles of denaturation at $94^{\circ} \mathrm{C}$ for $30 \mathrm{~s}$, annealing at $54^{\circ} \mathrm{C}$ for $30 \mathrm{~s}$, the extension at $72^{\circ} \mathrm{C}$ for $1 \mathrm{~min}$ and a final extension at $72{ }^{\circ} \mathrm{C}$ for $10 \mathrm{~min}$.

\section{Electrophoresis of $P C R$ products}

PCR products were subject to electrophoresis using $1.5 \%$ agarose gel in $0.5 \mathrm{X}$ TBE buffer $(0.1 \mathrm{M}$ Tris, $0.1 \mathrm{M}$ boric acid and $0.002 \mathrm{M}$ NaEDTA). A 100-bp DNA ladder (Thermo Scientific, USA) was used as a molecular

Table 8 The PCR primers used in this study

\begin{tabular}{|c|c|c|c|}
\hline Target gene & Primer sequence $\left(5^{\prime} \rightarrow 3^{\prime}\right)$ & $\begin{array}{l}\text { Amplicon } \\
\text { size (bp) }\end{array}$ & Reference \\
\hline blaz & $\begin{array}{l}\text { F: TGA CCA CTT TTA TCA GCA } \\
\text { ACC } \\
\text { R: GCC ATT TCA ACA CCTTCT } \\
\text { TTC }\end{array}$ & 700 & {$[93,94]$} \\
\hline mecA & $\begin{array}{l}\text { F: AAA ATC GAT GGT AAA GGT } \\
\text { TGG C } \\
\text { R: AGT TCT GCA GTA CCG GAT } \\
\text { TTG C }\end{array}$ & 532 & [95-97] \\
\hline$b l a_{\mathrm{TEM}}$ & $\begin{array}{l}\text { F: ATC AGC AAT AAA CCA GC } \\
\text { R: CCC CGA AGA ACG TTTTC }\end{array}$ & 516 & [98-100] \\
\hline$b l a_{\mathrm{SHV}}$ & $\begin{array}{l}\text { F: AGG ATT GAC TGC CTTTTTT G } \\
\text { R: ATT TGC TGA TTT CGC TCG }\end{array}$ & 392 & [101-103] \\
\hline
\end{tabular}

size standard. The gel was stained with $0.1 \%$ ethidium bromide, allowed to run at $75 \mathrm{~V}$ for $90 \mathrm{~min}$. The amplicons were visualized under UV light using a Gel documentation system (Biorad, USA).

\section{Statistical analysis}

All measurements were performed in triplicate. The total microbial counts were calculated as $\log \mathrm{CFU} / \mathrm{g}$ and presented as the mean \pm standard deviation. The data were analyzed by the chi-square test and Fisher's exact test using SPSS 16.0 software (SPSS Inc., Chicago, IL, USA). The results were considered to be statistically different at 95\% confidence levels.

\section{Abbreviations}

BSA: Bismuth sulphite agar; BGLB: Brilliant green bile lactose broth; BGA: Brilliant green phenol red agar; CAMP: Christie-Atkins-Munch-Peterson; CFU: Colony-forming unit; CLSI: Clinical laboratory standards Institute; DNase: Deoxyribonuclease; EMB: Eosin methylene blue; E. coli: Escherichia coli; ESBL: Extended-spectrum beta-lactamase; HEA: Hektoen enteric agar; LIA: Lysine iron agar; MR/NP: Methyl red and voges-proskauer; SC: Selenite cystine; SIM: Sulfide-indole-motility; S. aureus: Staphylococcus aureus; S. Enteritidis: S. Enteritidis; S. Typhimurium: SalmonellaTyphimurium; S. Pullorum: Salmonella Pullorum; L. monocytogenes: Listeria monocytogenes; PCR: Polymerase chain reaction; TBC: Total bacterial count; TBG: Tetrathionate brilliant green bile; TSA: Tryptic soy agar; RTE: Ready-to-eat; TSB: Trypticase soy broth; TSI: Triple sugar iron; XLD: Xylose lysine deoxycholate.

\section{Supplementary Information}

The online version contains supplementary material available at https://doi. org/10.1186/s12866-021-02326-8.

Additional file 1: Tables S1. Results of biochemical tests from the selected foodborne pathogens isolated from kebab and hamburger samples.

Additional file 2: Figure S1. Agarose gel electrophoresis of PCR amplification products of bla $a_{\text {TEM }}\left(516 \mathrm{bp}\right.$ ) and bla $a_{\mathrm{SHV}}(392 \mathrm{bp})$ from Escherichia coli isolates, L: Ladder (100 bp); Lane 1: positive control for bla $a_{\mathrm{TEM}}$; Lane 2: positive control for bla $a_{\text {SHVi }}$ Lanes 5, 7, 9 and 10: positive samples for bla $a_{\text {TEM }}$; Lanes 5 and 9: positive samples for bla $a_{\mathrm{SH}}$

Additional file 3: Figure S2. Agarose gel electrophoresis of PCR amplification products of mecA (532 bp) from Listeria monocytogenes isolates, L: Ladder (100 bp); Lanes 2, 3, 4 and 5: positive samples; Lane 6: positive control; Lane 7: negative control.

Additional file 4: Figure S3. Agarose gel electrophoresis of PCR amplification products of bla $a_{\mathrm{SHV}}(392 \mathrm{bp})$ and bla $a_{\mathrm{TEM}}(516 \mathrm{bp})$ genes from the isolates of Salmonella spp., L: Ladder (100 bp); Lanes 1: positive samples for bla $a_{\mathrm{TEM}}$, Lanes 2 and 3: positive samples for bla $a_{\mathrm{SHV}}$ bla $a_{\mathrm{TEM}}$ : Lane 6: positive control for bla $a_{\mathrm{SHV}}$ bla $a_{\mathrm{TEM}}$; Lane 7: negative control.

Additional file 5: Figure S4. Agarose gel electrophoresis of PCR amplification products of mecA (532 bp) and bla $(700 \mathrm{bp}$ ) from Staphylococcus aureus isolates, L: Ladder (100 bp); Lanes 2: positive sample for mecA and bla $_{z}$; Lanes 3 and 4: positive samples for mecA; Lanes 5: positive control for mecA and bla $a_{z}$ Lane 6: negative control.

\footnotetext{
Acknowledgments

Authors are grateful to the vice-chancellorship for research and technology, University of Tabriz for their financial support in performing this research.
} 


\section{Authors' contributions}

Maryam Rajaei: Data curation, Formal analysis, Funding, Investigation, Project administration, Resources, Visualization. Mir-Hassan Moosavy: Conceptualization, Funding, Methodology, Resources, Supervision, Validation, Visualization, Role/ Writing - original draft, Writing - review \& editing. Sahar Nouri Gharajalar: Conceptualization, Data curation, Formal analysis, Investigation, Methodology, Project administration, Supervision, Validation. Seyed Amin Khatibi: Software, Supervision, Validation, Writing - review \& editing. All authors reviewed the manuscript. The authors read and approved the final manuscript.

\section{Funding}

The experimental work for this study was supported by ViceChancellery for Research and Technology, University of Tabriz (grant ID: 43.8640).

\section{Availability of data and materials}

The datasets generated and/or analysed during the current study are available in the Harvard Dataverse Repository, (https://doi.org/10.7910/DVN/EOLCXA).

\section{Declarations}

Ethics approval and consent to participate

Not applicable.

\section{Consent for publication}

Not applicable.

\section{Competing interests}

The authors declare that they have no competing interests.

\section{Author details}

${ }^{1}$ Department of Food Hygiene and Aquatic, Faculty of Veterinary Medicine, University of Tabriz, Tabriz, Iran. ${ }^{2}$ Department of Pathobiology, Faculty of Veterinary Medicine, University of Tabriz, Tabriz, Iran.

Received: 15 December 2020 Accepted: 27 September 2021 Published online: 07 October 2021

\section{References}

1. Adzitey F. Incidence and antimicrobial susceptibility of Escherichia coli isolated from beef (meat muscle, liver and kidney) samples in Wa abattoir, Ghana. Cogent Food Agric. 2020;6(1):1718269 https://doi.org/10. 1080/23311932.2020.1718269.

2. Khatibi SA, Hamidi S, Siahi-Shadbad MR. Current trends in sample preparation by solid-phase extraction techniques for the determination of antibiotic residues in foodstuffs: a review. Crit Rev Food Sci Nutr. 2020:1-22 https://doi.org/10.1080/10408398.2020.1798349.

3. Khatibi SA, Hamidi S, Siahi-Shadbad MR. Application of liquid-liquid extraction for the determination of antibiotics in the foodstuff: recent trends and developments. Crit Rev Anal Chem. 2020:1-16 https://doi. org/10.1080/10408347.2020.1798211.

4. González-Gutiérrez M, García-Fernández C, Alonso-Calleja C, Capita R. Microbial load and antibiotic resistance in raw beef preparations from Northwest Spain. Food Sci Nutr. 2020;8(2):777-85. https://doi.org/10. 1002/fsn3.1319.

5. Javadi A, Khatibi SA. Effect of commercial probiotic (Protexin ${ }^{\circledR}$ ) on growth, survival and microbial quality of shrimp (Litopenaeus vannamei). Nutr Food Sci. 2017;47(2):204-16 https://doi.org/10.1108/ NFS-07-2016-0085.

6. Algammal A, Mabrok M. Pathogenicity, genetic typing, and antibiotic sensitivity of vibrio alginolyticus isolated from Oreochromis niloticus and Tilapia zillii. Rev Med Vet. 2019;170:80-6.

7. Algammal AM, El-Sayed ME, Youssef FM, Saad SA, Elhaig MM, Batiha $\mathrm{GE}$, et al. Prevalence, the antibiogram and the frequency of virulence genes of the most predominant bacterial pathogens incriminated in calf pneumonia. AMB Express. 2020;10(1):99 https://doi.org/10.1186/ s13568-020-01037-z.

8. Algammal AM, Enany ME, El-Tarabili RM, Ghobashy MOI, Helmy YA. Prevalence, antimicrobial resistance profiles, virulence and enterotoxins-determinant genes of MRSA isolated from subclinical bovine mastitis in Egypt. Pathogens. 2020;9(5):362 https://doi.org/10. 3390/pathogens9050362.

9. Algammal AM, Hetta HF, Elkelish A, Alkhalifah DHH, Hozzein WN, Batiha GE-S, et al. Methicillin-resistant Staphylococcus aureus (MRSA): one health perspective approach to the bacterium epidemiology, virulence factors, antibiotic-resistance, and zoonotic impact. Infect Drug Resist. 2020;13:3255-65 https://doi.org/10.2147/IDR.S272733.

10. Algammal AM, Mabrok M, Sivaramasamy E, Youssef FM, Atwa MH, El-kholy AW, et al. Emerging MDR-Pseudomonas aeruginosa in fish commonly harbor oprL and toxA virulence genes and blaTEM, blaCTX-M, and tetA antibiotic-resistance genes. Sci Rep. 2020;10(1):15961 https:// doi.org/10.1038/s41598-020-72264-4.

11. Algammal AM, Mohamed MF, Tawfiek BA, Hozzein WN, El Kazzaz WM, Mabrok M. Molecular typing, antibiogram and PCR-RFLP based detection of Aeromonas hydrophila complex isolated from Oreochromis niloticus. Pathogens. 2020;9(3):238 https://doi.org/10.3390/pathogens9 030238

12. Enany $M E$, Algammal AM, Nasef SA, Abo-Eillil SAM, Bin-Jumah M, Taha $A E$, et al. The occurrence of the multidrug resistance (MDR) and the prevalence of virulence genes and QACs resistance genes in $E$. coli isolated from environmental and avian sources. AMB Express. 2019;9(1):192 https://doi.org/10.1186/s13568-019-0920-4.

13. Abolghait SK, Fathi AG, Youssef FM, Algammal AM. Methicillin-resistant Staphylococcus aureus (MRSA) isolated from chicken meat and giblets often produces staphylococcal enterotoxin B (SEB) in non-refrigerated raw chicken livers. Int J Food Microbiol. 2020;328:108669 https://doi. org/10.1016/j.ijfoodmicro.2020.108669.

14. Novovic K, Mihajlovic S, Vasiljevic Z, Filipic B, Begovic J, Jovcic B. Carbapenem-resistant Acinetobacter baumannii from Serbia: revision of CarO classification. PLoS One. 2015;10(3):e0122793 https://doi.org/10. 1371/journal.pone.0122793.

15. Newell DG, Koopmans M, Verhoef L, Duizer E, Aidara-Kane A, Sprong H, et al. Food-borne diseases - the challenges of 20 years ago still persist while new ones continue to emerge. Int J Food Microbiol. 2010;139:S3S15 https://doi.org/10.1016/j.ijfoodmicro.2010.01.021.

16. Pereira PM, Vicente AF. Meat nutritional composition and nutritive role in the human diet. Meat Sci. 2013;93(3):586-92 https://doi.org/10. 1016/j.meatsci.2012.09.018.

17. Campos J, Gil J, Mourão J, Peixe L, Antunes P. Ready-to-eat streetvended food as a potential vehicle of bacterial pathogens and antimicrobial resistance: an exploratory study in Porto region, Portugal. Int J Food Microbiol. 2015;206:1-6 https://doi.org/10.1016/j.ijfoodmicro. 2015.04.016.

18. Gilani A, Razavilar V, Rokni N, Rahimi E. VacA and cagA genotypes status and antimicrobial resistance properties of helicobacter pylori strains isolated from meat products in Isfahan province, Iran. Iran J Vet Res. 2017;18(2):97-102 https://doi.org/10.22099/ijvr.2017.4088.

19. Obeid R, Heil SG, Verhoeven MMA, van den Heuvel EGHM, de Groot LCPGM, Eussen SJPM. Vitamin B12 intake from animal foods, biomarkers, and health aspects. Front Nutr. 2019;6:93.

20. Altaf Hussain M, Wang W, Sun C, Gu L, Liu Z, Yu T, et al. Molecular characterization of pathogenic Salmonella spp. from raw beef in Karachi, Pakistan. Antibiotics. 2020;9(2):73 https://doi.org/10.3390/antibiotic s9020073.

21. Latha C, Anu CJ, Ajaykumar VJ, Sunil B. Prevalence of Listeria monocytogenes, Yersinia enterocolitica, Staphylococcus aureus, and Salmonella enterica Typhimurium in meat and meat products using multiplex polymerase chain reaction. Vet World. 2017;10(8):927-31 https://doi. org/10.14202/vetworld.2017.927-931.

22. Abebe E, Gugsa G, Ahmed M. Review on major food-borne zoonotic bacterial pathogens. J Trop Med. 2020;2020:4674235 https://doi.org/10. 1155/2020/4674235.

23. Ebrahimi A, Moosavy M-H, Khatibi SA, Barabadi Z, Hajibemani A. A comparative study of the antibacterial properties of milk from different domestic animals. Int J Dairy Technol. 2021;74(2):425-30. https://doi. org/10.1111/1471-0307.12757.

24. Khatibi SA, Misaghi A, Moosavy MH, Akhondzadeh Basti A, Mohamadian S, Khanjari A. Effect of nanoliposomes containing Zataria multiflora Boiss. essential oil on gene expression of Shiga toxin 2 in Escherichia coli 
O157:H7. J Appl Microbiol. 2018;124(2):389-97. https://doi.org/10.1111/ jam.13641.

25. Khatibi SA, Misaghi A, Moosavy M-H, Basti AA, Koohi MK, Khosravi $P$, et al. Encapsulation of Zataria multiflora Bioss. essential oil into nanoliposomes and in vitro antibacterial activity against Escherichia coli O157:H7. J Food Process Preserv. 2017;41 (3):e12955. https://doi.org/10. 1111/jfpp. 12955.

26. Moosavy M-H, Esmaeili S, Mortazavian AM, Mostafavi E, Habibi-Asl B, Hosseini $\mathrm{H}$, et al. Behaviour of Listeria monocytogenes in Lighvan cheese following artificial contamination during making, ripening and storage in different conditions. Int J Dairy Technol. 2017;70(3):365-71.https:// doi.org/10.1111/1471-0307.12372.

27. Ahmed AM, Shimamoto T. Molecular analysis of multidrug resistance in Shiga toxin-producing Escherichia coli O157:H7 isolated from meat and dairy products. Int J Food Microbiol. 2015;193:68-73. https://doi.org/10. 1016/j.jiffoodmicro.2014.10.014.

28. Doğruer Y, Telli N, Telli E, Güner A. Presence and antibiotic susceptibility of Listeria monocytogenes in retail meat and meat products. Int J Biol Res. 2015;3:76 https://doi.org/10.14419/ijbr.v3i2.5323.

29. Chajęcka-Wierzchowska W, Zadernowska A, Łaniewska-Trokenheim $七$. Diversity of antibiotic resistance genes in Enterococcus strains isolated from ready-to-eat meat products. J Food Sci. 2016;81 (11):M2799m2807 https://doi.org/10.1111/1750-3841.13523.

30. Aguilar-Montes de Oca S, Talavera-Rojas M, Soriano-Vargas E, BarbaLeón J, Vázquez-Navarrete J, Acosta-Dibarrat J, et al. Phenotypic and genotypic profile of clinical and animal multidrug-resistant Salmonella enterica isolates from Mexico. J Appl Microbiol. 2018;124(1):67-74 https://doi.org/10.1111/jam.13615.

31. Jaja IF, Bhembe NL, Green E, Oguttu J, Muchenje V. Molecular characterisation of antibiotic-resistant Salmonella enterica isolates recovered from meat in South Africa. Acta Trop. 2019;190:129-36 https://doi.org/ 10.1016/j.actatropica.2018.11.003.

32. CLSI. Performance standards for antimicrobial susceptibility testing. 28th ed. CLSI supplement M100.; Clinical and laboratory standards institute. 2018. available at: https://clsi.org/media/1930/m100ed28 sample.pdf. (accessed 04 May 2020).

33. CLSI. Methods for antimicrobial dilution and disk susceptibility testing of infrequently isolated or fastidious bacteria. 3th ed. CLSI guideline M45; Clinical and Laboratory Standards Institute. 2015. available at: https:/clsi.org/standards/products/microbiology/documents/m45/. (accessed 04 May 2020).

34. Hansen JM, Gerner-Smidt P, Bruun B. Antibiotic susceptibility of Listeria monocytogenes in Denmark 1958-2001. Apmis. 2005;113(1):31-6 https://doi.org/10.1111/j.1600-0463.2005.apm1130105.x.

35. CA-SFM. Comité de l'Antibiogramme de la Société Française de Microbiologie Report 2003. Int J Antimicrob Agents. 2003;21(4):364-91. https://doi.org/10.1016/S0924-8579(03)00021-9.

36. Soussy CJ, Cluzel R, Courvalin P. Definition and determination of in vitro antibiotic susceptibility breakpoints for bacteria in France. The Comité de I'Antibiogramme de la Société Française de Microbiologie. Eur J Clin Microbiol Infect Dis. 1994;13(3):238-46 https://doi.org/10.1007/bf019 74543.

37. Dewey-Mattia D, Manikonda K, Hall AJ, Wise ME, Crowe SJ. Surveillance for foodborne disease outbreaks - United States, 2009-2015. MMWR Morb Mortal Wkly Rep Surveill Summ. 2018;67(10):1-11 https://doi.org/ 10.15585/mmwr.ss6710a1.

38. Hawkes C, Blouin C, Henson S, Drager N, Dubé L. Trade, food, diet and health: perspectives and policy options. West Sussex: Wiley; 2009.

39. Communities, CotE. Commission Regulation (EC) No. 2073/2005 of 15 November 2005 on microbiological criteria for foodstuffs. OJEU. 2005;L 338:1-29.

40. ICMSF. Microorganisms in foods 8 . Use of data for assessing process control and product acceptance. New York: Springer; 2011.

41. IFST. Development and use of microbiological criteria for foods. Food Sci Technol Today. 1997;11:137-76.

42. Andritsos ND, Mataragas M, Mavrou E, Stamatiou A, Drosinos EH. The microbiological condition of minced pork prepared at retail stores in Athens, Greece. Meat Sci. 2012;91(4):486-9. https://doi.org/10.1016/j. meatsci.2012.02.036.

43. Siriken B. The microbiological quality of ground beef. Rev Med Vet. 2004;155:632-6.
44. Cho JI, Cheung CY, Lee SM, Ko SI, Kim KH, Hwang IS, et al. Assessment of microbial contamination levels of street-vended foods in Korea. J Food Saf. 2011;31(1):41-7 https://doi.org/10.1111/j.1745-4565.2010.00264.x.

45. Hemeg HA. Molecular characterization of antibiotic resistant Escherichia coli isolates recovered from food samples and outpatient clinics, KSA. Saudi J Biol Sci. 2018;25(5):928-31. https://doi.org/10.1016/j.sjbs.2018. 01.016.

46. Zelalem A, Sisay M, Vipham JL, Abegaz K, Kebede A, Terefe Y. The prevalence and antimicrobial resistance profiles of bacterial isolates from meat and meat products in Ethiopia: a systematic review and meta-analysis. Int J Food Contam. 2019;6(1):1 https://doi.org/10.1186/ s40550-019-0071-z.

47. Sunabe T, Honma Y. Relationship between O-serogroup and presence of pathogenic factor genes in Escherichia coli. Microbiol Immunol. 1998;42(12):845-9 https://doi.org/10.1111/j.1348-0421.1998.tb02360.x.

48. Seas C, Alarcon M, Aragon JC, Beneit S, Quiñonez M, Guerra H, et al. Surveillance of bacterial pathogens associated with acute diarrhea in Lima, Peru. Int J Infect Dis. 2000;4(2):96-9 https://doi.org/10.1016/ s1201-9712(00)90101-2.

49. Koo HJ, Woo GJ. Distribution and transferability of tetracycline resistance determinants in Escherichia coli isolated from meat and meat products. Int J Food Microbiol. 2011;145(2-3):407-13 https://doi.org/10. 1016/j.jifoodmicro.2011.01.003.

50. Osterblad M, Hakanen A, Manninen R, Leistevuo T, Peltonen R, Meurman $\mathrm{O}$, et al. A between-species comparison of antimicrobial resistance in enterobacteria in fecal flora. Antimicrob Agents Chemother. 2000;44(6):1479-84 https://doi.org/10.1128/aac.44.6.1479-1484.2000.

51. Van den Bogaard AE, Stobberingh EE. Epidemiology of resistance to antibiotics. Links between animals and humans. Int J Antimicrob Agents. 2000;14(4):327-35 https://doi.org/10.1016/s0924-8579(00) 00145-X.

52. Alegría Á, Arias Temprano M, Fernández-Natal I, Rodríguez-Calleja J, García-López ML, Santos J. Molecular diversity of ESBL-producing Escherichia coli from foods of animal origin and human patients. Int J Environ Res Public Health. 2020;17:1312 https://doi.org/10.3390/ijerp h17041312

53. Ramadan H, Jackson C, Hiott L, Samir M, Awad A, Woodley T. Antimicrobial resistance, genetic diversity and multilocus sequence typing of Escherichia coli from humans, retail chicken and ground beef in Egypt. Pathogens. 2020;9:357 https://doi.org/10.3390/pathogens9050357.

54. Helfand MS, Bonomo RA. Current challenges in antimicrobial chemotherapy: the impact of extended-spectrum beta-lactamases and metallo-beta-lactamases on the treatment of resistant gram-negative pathogens. COPHAR. 2005;5(5):452-8 https://doi.org/10.1016/j.coph. 2005.04.013.

55. Schmid A, Hörmansdorfer S, Messelhäusser U, Käsbohrer A, SauterLouis C, Mansfeld R. Prevalence of extended-spectrum $\beta$-lactamaseproducing Escherichia coli on Bavarian dairy and beef cattle farms. Appl Environ Microbiol. 2013;79(9):3027-32 https://doi.org/10.1128/aem. 00204-13.

56. Maung AT, Mohammadi TN, Nakashima S, Liu P, Masuda Y, Honjoh $\mathrm{K}-\mathrm{I}$, et al. Antimicrobial resistance profiles of Listeria monocytogenes isolated from chicken meat in Fukuoka, Japan. Int J Food Microbiol. 2019;304:49-57. https://doi.org/10.1016/j.ijfoodmicro.2019.05.016.

57. Pesavento G, Ducci B, Nieri D, Comodo N, Lo Nostro A. Prevalence and antibiotic susceptibility of Listeria spp. isolated from raw meat and retail foods. Food Control. 2010;21:708-13 https://doi.org/10.1016/j.foodcont. 2009.10.012.

58. Ozbey G, Icyeroglu A, Muz A. Prevalence of Listeria species in raw hamburger meatballs and chicken burgers in eastern Turkey. Afr J Microbiol Res. 2013;7(31):4055-8.

59. Yang S, Pei X, Wang G, Yan L, Hu J, Li Y, et al. Prevalence of food-borne pathogens in ready-to-eat meat products in seven different Chinese regions. Food Control. 2016;65:92-8. https://doi.org/10.1016/j.foodcont. 2016.01.009.

60. Nemati V, Khomeiri M, Sadeghi Mahoonak A, Moayedi A. Prevalence and antibiotic susceptibility of Listeria monocytogenes isolated from retail ready-to-eat meat products in Gorgan, Iran. Nutr Food Sci Res. 2020;7(1):41-6 https://doi.org/10.29252/nfsr.7.1.41. 
61. Wang TS, Wang Y, He CY, Ye ZX, Wang Y, Xu K, et al. Detection of drug susceptibility and resistant genes in selected food borne Listeria monocytogens in China. Dis Surveill. 2013;28(3):224-9.

62. Roy P, Dhillon AS, Lauerman LH, Schaberg DM, Bandli D, Johnson S. Results of salmonella isolation from poultry products, poultry, poultry environment, and other characteristics. Avian Dis. 2002;46(1):17-24. https://doi.org/10.1637/0005-2086(2002)046[0017:rosifp]2.0.co;2.

63. Gill CO, Jones T. The presence of Aeromonas, Listeria and Yersinia in carcass processing equipment at two pig slaughtering plants. Food Microbiol. 1995;12:135-41. https://doi.org/10.1016/S0740-0020(95) 80089-1.

64. Molla B, Alemayehu D, Abdela W. Sources and distribution of Salmonella serotypes isolated from food animals, slaughterhouse personnel and retail meat products in Ethiopia: 1997-2002. EJHD. 2002;17(1):63-70 https://doi.org/10.4314/ejhd.v17i1.9782.

65. Taghizadeh M, Javadian B, Rafiei A, Taraghian A, Moosazadeh M. Antimicrobial resistance and virulence of Salmonella spp. from foods in Mazandaran. Res Mol Med. 2019;7(2):9-18.

66. Brooks GF, Butel JS, Morse SA. Cultivation of microorganisms. In: Brooks GF, Butel JS, Morse SA, editors. Jawetz, Melnick \& Adelberg's medical microbiology. New York: McGraw-Hill Medical; 2004. p. 62-4.

67. Davis MA, Hancock DD, Besser TE, Rice DH, Gay JM, Gay C, et al. Changes in antimicrobial resistance among Salmonella enterica serovar Typhimurium isolates from humans and cattle in the northwestern United States, 1982-1997. Emerg Infect Dis. 1999;5(6):802-6 https://doi. org/10.3201/eid0506.990610.

68. Su L-H, Wu T-L, Chia J-H, Chu C, Kuo A-J, Chiu C-H. Increasing ceftriaxone resistance in Salmonella isolates from a university hospital in Taiwan. J Antimicrob Chemother. 2005;55(6):846-52 https://doi.org/10. 1093/jac/dki116.

69. Fortuna J, Nascimento E, Franco R. Antimicrobial resistance of Salmonella spp. strains isolated from hamburgers. Afr J Microbiol Res. 2013;6:7525-33 https://doi.org/10.5897/AJMR12.2084.

70. Moawad AA, Hotzel H, Awad O, Tomaso H, Neubauer H, Hafez HM, et al. Occurrence of Salmonella enterica and Escherichia coli in raw chicken and beef meat in northern Egypt and dissemination of their antibiotic resistance markers. Gut Pathog. 2017;9:57 https://doi.org/10.1186/ s13099-017-0206-9.

71. Aslam M, Checkley S, Avery B, Chalmers G, Bohaychuk V, Gensler G, et al. Phenotypic and genetic characterization of antimicrobial resistance in Salmonella serovars isolated from retail meats in Alberta, Canada. Food Microbiol. 2012;32(1):110-7. https://doi.org/10.1016/j.fm.2012.04.017.

72. Moosavy MH, Hassanzadeh P, Mohammadzadeh E, Mahmoudi R, Khatibi SA, Mardani K. Antioxidant and antimicrobial activities of essential oil of Lemon (Citrus limon) peel in vitro and in a food model. ssu-jfahc. 2017:4(2):42-8.

73. Aycicek H, Cakiroglu S, Stevenson TH. Incidence of Staphylococcus aureus in ready-to-eat meals from military cafeterias in Ankara, Turkey. Food Control. 2005;16(6):531-4. https://doi.org/10.1016/j.foodcont. 2004.04.005.

74. Shahraz F, Dadkhah $H$, Khaksar R, Mahmoudzadeh M, Hosseini $H_{\text {, }}$ Kamran M, et al. Analysis of antibiotic resistance patterns and detection of mecA gene in Staphylococcus aureus isolated from packaged hamburger. Meat Sci. 2012;90(3):759-63 https://doi.org/10.1016/j.meatsci. 2011.11.009.

75. Chajęcka-Wierzchowska W, Zadernowska A, Łaniewska-Trokenheim $Ł$. Staphylococcus aureus from ready-to-eat food as a source of multiple antibiotic resistance genes. CBU Int Conf Proc. 2017;5:1 108 https://doi. org/10.12955/cbup.v5.1079.

76. Arafa A, Ibrahim ES, Fouad E, Gaber ES. Antibiotic resistance of staphylococci concerning strains included in food industry in Egypt. Int J Pharm Clin Res. 2016;8:1583-9.

77. Çetinkaya F, Elal Mus T. Detection of antibiotic resistance in Staphylococcus aureus strains isolated from various foods. Uludağ Üniv Vet Fak Derg. 2012;2:31-42.

78. Baghbaderani Z, Shakerian A, Rahimi E. Phenotypic and genotypic assessment of antibiotic resistance of Staphylococcus aureus bacteria isolated from retail meat. Infect Drug Resist. 2020;13:1339-49 https:// doi.org/10.2147/IDR.S241189.

79. Olsen JE, Christensen H, Aarestrup FM. Diversity and evolution of blaZ from Staphylococcus aureus and coagulase-negative staphylococci. J
Antimicrob Chemother. 2006;57(3):450-60 https://doi.org/10.1093/jac/ dki492.

80. Davis MA, Besser TE, Orfe LH, Baker KNK, Lanier AS, Broschat SL, et al Genotypic-phenotypic discrepancies between antibiotic resistance characteristics of Escherichia coli isolates from calves in management settings with high and low antibiotic use. Appl Environ Microbiol. 2011;77(10):3293-9 https://doi.org/10.1128/AEM.02588-10.

81. Smith M, Do TN, Gibson JS, Jordan D, Cobbold RN, Trott DJ. Comparison of antimicrobial resistance phenotypes and genotypes in enterotoxigenic Escherichia coli isolated from Australian and Vietnamese pigs. J Glob Antimicrob Resist. 2014;2(3):162-7. https://doi.org/10.1016/j.jgar. 2014.03.008.

82. Ghazaei C. Phenotypic and molecular detection of beta-lactamase enzyme produced by Bacillus cereus isolated from pasteurized and raw milk. J Med Bacteriol. 2018;8(3-4):1-7.

83. Hitchins AD, Jinneman K, Chen Y. BAM chapter 10: detection of Listeria monocytogenes in foods and environmental samples, and enumeration of Listeria monocytogenes in foods: Food and Drug Administration; 2017. available at: https://www.fda.gov/food/laboratory-methods-food/ bam-chapter-10-detection-listeria-monocytogenes-foods-and-envir onmental-samples-and-enumeration. (accessed 01 Apr 2021)

84. Maharjan S, Rayamajhee B, Chhetri VS, Sherchan SP, Panta OP, Karki TB. Microbial quality of poultry meat in an ISO 22000:2005 certified poultry processing plant of Kathmandu valley. Int J Food Contam. 2019;6(1):8 https://doi.org/10.1186/s40550-019-0078-5.

85. Feng, P, Weagant, SD, Grant, MA, Burkhardt, W, Shellfish, M, Water, B. Bacteriological analytical manual: enumeration of Escherichia coli and the coliform bacteria; 2002. available at: www.fda.gov/Food/FoodS cienceResearch/LaboratoryMethods/ucm064948.htm\#fn1. (accessed 13 June 2020).

86. Ombarak R, Hinenoya A, Awasthi S, Iguchi A, Shima A, Elbagory A, et al. Prevalence and pathogenic potential of Escherichia coli isolates from raw milk and raw milk cheese in Egypt. Int J Food Microbiol. 2016;221:69-76 https://doi.org/10.1016/j.ijfoodmicro.2016.01.009.

87. Barrow G, Feltham R. Cowan and Steel's manual for the identification of medical bacteria. Cambridge: Cambridge University Press; 1993.

88. Mayrhofer S, Paulsen P, Smulders FJ, Hilbert F. Antimicrobial resistance profile of five major food-borne pathogens isolated from beef, pork and poultry. Int J Food Microbiol. 2004;97(1):23-9 https://doi.org/10.1016/j. ijfoodmicro.2004.04.006.

89. Andrews WH, FR, Siliker J, Bailey JS, Labbe RG. Salmonella. In: Downes FPIK, editor. Compendium of methods for the microbiological examination of foods. Washington: American Public Health Association; 2001. p. 357-80.

90. Bauer AW, Kirby WM, Sherris JC, Turck M. Antibiotic susceptibility testing by a standardized single disk method. Am J Clin Pathol. 1966;45(4):493-6.

91. Cornaglia G, Hryniewicz W, Jarlier V, Kahlmeter G, Mittermayer H, Stratchounski $L$, et al. European recommendations for antimicrobial resistance surveillance. Clin Microbiol Infect. 2004;10(4):349-83 https:// doi.org/10.1111/j.1198-743X.2004.00887.x

92. Nayak R, Stewart TM, Nawaz MS. PCR identification of campylobacter coli and campylobacter jejuni by partial sequencing of virulence genes. Mol Cell Probes. 2005;19(3):187-93 https://doi.org/10.1016/j.mcp.2004.11. 005.

93. Kang MH, Chae MJ, Yoon JW, Kim SG, Lee SY, Yoo JH, et al. Antibiotic resistance and molecular characterization of ophthalmic Staphylococcus pseudintermedius isolates from dogs. J Vet Sci. 2014;15(3):409-15 https://doi.org/10.4142/jvs.2014.15.3.409.

94. Meroni G, Soares Filipe JF, Drago L, Martino PA. Investigation on antibiotic-resistance, biofilm formation and virulence factors in multi drug resistant and non multi drug resistant Staphylococcus pseudintermedius. Microorganisms. 2019;7(12):702 https://doi.org/10.3390/micro organisms 7120702

95. Shahmohammadi MR, Nahaei MR, Akbarzadeh A, Milani M. Clinical test to detect mecA and antibiotic resistance in Staphylococcus aureus, based on novel biotechnological methods. Artif Cells Nanomed Biotechnol. 2016;44(6):1464-8 https://doi.org/10.3109/21691401.2015. 1041639.

96. Rocchetti TT, Martins KB, Martins PYF, Oliveira RA, Mondelli AL, Fortaleza $C$, et al. Detection of the mecA gene and identification of 
Staphylococcus directly from blood culture bottles by multiplex polymerase chain reaction. Braz J Infect Dis. 2018;22(2):99-105 https://doi. org/10.1016/j.bjid.2018.02.006.

97. Kim YH, Kim HS, Kim S, Kim M, Kwak HS. Prevalence and characteristics of antimicrobial-resistant Staphylococcus aureus and methicillinresistant Staphylococcus aureus from retail meat in Korea. Food Sci Anim Resour. 2020;40(5):758-71 https://doi.org/10.5851/kosfa.2020.e50.

98. Lyimo B, Buza J, Subbiah M, Smith W, Call DR. Comparison of antibiotic resistant Escherichia coli obtained from drinking water sources in northern Tanzania: a cross-sectional study. BMC Microbiol. 2016;16(1):254 https://doi.org/10.1186/s12866-016-0870-9.

99. Abdel Aziz SA, Abdel-Latef GK, Shany SAS, Rouby SR. Molecular detection of integron and antimicrobial resistance genes in multidrug resistant Salmonella isolated from poultry, calves and human in Beni-Suef governorate, Egypt. BJBAS. 2018;7(4):535-42 https://doi.org/10.1016/j. bjbas.2018.06.005.

100. Eid S, Samir AH. Extended-spectrum beta-lactamase and Class 1 integrons in multidrug-resistant Escherichia coli isolated from turkeys. Vet World. 2019;12(7):1167-74 https://doi.org/10.14202/vetworld.2019. $1167-1174$
101. Tew LS, She LY, Chew CH. Isolation, antimicrobial susceptibility profile and detection of Sul1, blaTEM, and blaSHV in amoxicillin-clavulanateresistant bacteria isolated from retail sausages in Kampar, Malaysia. Jundishapur J Microbiol. 2016;9(10):e37897 https://doi.org/10.5812/jjm. 37897.

102. Abrar S, Ain NU, Liaqat H, Hussain S, Rasheed F, Riaz S. Distribution of blaCTX - M, blaTEM, blaSHV and blaOXA genes in extended-spectrum$\beta$-lactamase-producing clinical isolates: a three-year multi-center study from Lahore, Pakistan. Antimicrob Resist Infect Control. 2019;8(1):80 https://doi.org/10.1186/s13756-019-0536-0.

103. Yukawa S, Uchida I, Tamura Y, Ohshima S, Hasegawa T. Characterisation of antibiotic resistance of Salmonella isolated from dog treats in Japan. Epidemiol Infect. 2019;147:e102 https://doi.org/10.1017/s095026881 9000153.

\section{Publisher's Note}

Springer Nature remains neutral with regard to jurisdictional claims in published maps and institutional affiliations.
Ready to submit your research? Choose BMC and benefit from:

- fast, convenient online submission

- thorough peer review by experienced researchers in your field

- rapid publication on acceptance

- support for research data, including large and complex data types

- gold Open Access which fosters wider collaboration and increased citations

- maximum visibility for your research: over $100 \mathrm{M}$ website views per year

At BMC, research is always in progress.

Learn more biomedcentral.com/submissions 